are nearly all found in the bark of broad-leaved trees of the northern hemisphere, and with very few exceptions each is characteristically associated with one genus of host plants.

The perithecia are formed in groups in or below stromata which, unlike those of Diaporthe, are not normally associated with black zones of fungus tissue. The primary characters that have traditionally served for distributing the species into different genera are the colour, the septation and the appendages of the ascospores. Often locules are found within the young stromata, or acervuli on their flanks, and from these are produced conidia of two sorts, the broad so-called alpha- and the narrow beta-conidia. Partly through ignorance of the facts, and partly, despite the facts, out of deference to Saccardo's monumental "Sylloge", the perithecia and the two sorts of conidia of the same species have often enough been studied independently of one another; and so have acquired each their vested interest in the systematist's apprehension, and an independent name in his schizophrenic nomenclature. Thus, for example, the single species Melanconis thelebola has been made the type species of the three following genera : Pseudovalsella von Höhnel for use when it is found producing its perithecia; Hendersoniopsis von Höhnel for use when it is found forming its alpha-conidia, and Cytosporopsis von Höhnel for use when it is found forming its beta-conidia.

It is Dr. Wehmeyer's particular mission to join together again what has been so unnaturally put asunder ; and this he accomplishes by describing and often figuring each available species in all its known forms. He has included under Melanconis all the relevant species with one-septate ascospores, whether hyaline or dark-coloured, and either with or without appendages; and has grouped them into a number of proposed subgenera. Of these, Eu-melanconsis includes all the species with alpha-conidia one-celled, brown or hyaline, and borne in open acervuli-as, for example, the abundant British $M$. stilbosum on birch. Massariovalsa with similar alpha-conidia which are immersed in locules contains only two species, both of them North American; and Pseudomelanconis contains the species with many septate alpha-conidia of either of the Coryneum (that is, of the dry spored), or of the Steganosporium (that is, of the slimy spored) type. Pseudovalsa is restricted to take three species all with unappendaged several-septate ascospores, and fuscous stromata which bear several-septate alpha-conidia of the Coryneum type on an open hymenium. It includes the abundant British Pseudovalsa lanciformis on birch. Prosthecium, as here employed to take seven species, has several-septate appendaged ascospores, and stromata which bear in open or closed locules the several-septate alphaconidia.

Of the other genera, Titania is known only from the type collection of its type species, $T$. vesuvius; its asci each contain only a single ascospore.

In an appendix, the genus Calospora is revised away on the ground that its first species is a Melanconis; all the species included at various times in the genus have been examined and re-distributed. Thus Calospora platanoides, well known in Britain on sycamore, appears earlier in this monograph as Prosthecium innesii (Currey) Wehmeyer.

The genera Massaria, Aglaospora, Thyridaria and Pseudotrichia differ from all the foregoing in the presence, between the asci, of numerous filiform persistent paraphyses ; the author, however, is not yet satisfied that this character justifies their transfer from the Sphæriaceæ to a separate family, the Pseudosphæriaceæ.

It is a great pleasure to register a further stage of Dr. Wehmeyer's progress through the stromatic Sphæriaceæ. The very difficult group of Didymosporæ are now as good as done; and the Phragmosporæ are more than well begun.

E. W. Mason.

\section{WOUND INFECTIONS}

\section{Pathology and Treatment of War Wounds}

By Sir Almroth E. Wright. (Researches from the Inoculation Department, St. Mary's Hospital, London, W.2.) Pp. viii +208 . (London: William Heinemann (Medical Books), Ltd., 1942.) 21s. net. GIR ALMROTH WRIGHT has collected in this $\checkmark$ volume the addresses and papers upon wound infection that he published during the War of 1914-18. It is a fitting and salutary memorial of the pioneer work on a subject that was forced into prominence by the unprecedented casualties of that war. It is fitting because we can assess the large proportion of that work which has stood the test of time: and we can admire the brilliance of the experimental and technical devices invented by Sir Almroth and his colleagues, by which they were able to demonstrate the defensive action of leucocytes in open wounds and the connexion between 'corruption' and the loss in the tissue fluid of the power to neutralize the 'tryptic' processes of infection; and by which they defined the conditions in which a merely contaminated wound would flare up into gas gangrene, and measured the efficacy of the available methods of antibacterial treatment. It is salutary for its few examples of how too close an adherence to a technical approach, however fruitful, can be a stumbling block, as in the exploration of acidosis in the wounded subject by titrations in soft glass capillary pipettes.

It is obvious, however, that both the author and his publishers have not chosen a time like this to publish a volume that was only memorial in intention. Streptococcus pyogenes and Staphylococcus aureus are still bugbears of civil and military wounds, and gas gangrene is still with us. The treatment of infected wounds still presents many unsolved problems, and a great deal that Sir Almroth has taught deserves to be lifted out of the archives and set under the noses of surgeons and pathologists to-day. But as a lesson to a younger generation the collection would have been better for a little editing, if only to remove the occasional repetitions of experiments and text figures; and the force and precision with which the minutiæ of the experiments are displayed sometimes obscure the emphasis of the main argument.

A collection of papers like this needs a summary. Of his views in 1919, the author has presented a masterly exposition in the chapter on the physiology of wounds, which all who are concerned with the treatment of wounds would do well to read. The case for 'physiological' as against 'antiseptic' treatment still stands, but it does not stand quite so firmly. One would have liked an interpretation of these views in, the light of our present knowledge, particularly in chemotherapy and antisepsis. Sir Almroth might with some justice reply that our present knowledge is still too chaotic for a synthesis ; nevertheless it would have been valuable if he had attempted it.
A. A. Mrues. 